\title{
Human Resource Development Climate as a Predictor of Citizenship Behaviour and Voluntary Turnover Intentions in the Banking Sector
}

\author{
Akinyemi Benjamin \\ Department of Human Resource Management \\ School of Banking and Finance, Kigali, Rwanda \\ Tel: 250(0)-783-346-8279Ｅ-mail: akinyemi.ben@gmail.com
}

Received: September 14, 2011

Accepted: December 5, 2011

Published: January 1, 2012

doi:10.5539/ibr.v5n1p110

URL: http://dx.doi.org/10.5539/ibr.v5n1p110

\begin{abstract}
This study aims to examine the relationships among human resource development climate (HRDC), organisational citizenship behaviour (OCB) and voluntary turnover intentions (VTI) in the banking sector. Questionnaires were distributed to working adults in Nigerian commercial banks to guage the employees' individual perception, and thus data obtained was treated as an individual data source. About 600 questionnaires were distributed and a total of 303 were receieved representing a response rate of $50.5 \%$. Of these, 233 were usable for data analysis as others were incomplete. The results indicate that the HRDC has a significant relationship with OCB and VTI. However, OCB shows no significant relationship with VTI. The study findings and their implications for organisations in general and Nigerian banks in particular are discussed.
\end{abstract}

Keywords: Human Resource Development Climate, Voluntary turnover intention, Organisational citizenship behavior, Bank sector

\section{Introduction}

Hammonds (2005) emphasised the need for corporations to foster a productive work environment arguing that this should be considered as one of their most inmportant tasks. Today's business landscape is changing rapidly due to factors such as: globalization, responsiveness to customers, increasing revenue and decreasing costs, building organizational capability, change, and transformation, implementing technology, attracting and developing Human Capital, and ensuring fundamental and long-lasting change (Ulrich, 1997). The current volatile business environment and intense competition call for strategic and pragmatic approach towards employee development, engagement and effective utilisation. Contemporary organisations, especially the service industries, need to find better approach towards earning the commitment, motivation and loyalty of internal customers - the employees.

Organisational climate has been identified as having impact on employee attitudes and behaviours in the workplace. It is generally defined as the perceived structures, values, systems, and qualities of a particular organisation (Jones and James, 1979) or an individual's perception of organisational characteristics (Tracey et al., 1995). According to Mullins (2005, p.889), it is the "prevailing atmosphere surrounding the organisation, to the level of morale, and to the strength of feelings or belonging, care and goodwill among members." Mullins further stated that this prevailing climate can influence organisational members' attitudes which affect their work performance and inter-personal relationships. Organisational climate is largely perceptual in nature, being an employee's feelings and beliefs about the organisation. Developmental climate as a sub-set of organisational climate also influences the perception, attitude and behaviour of employees. It is an antecedent of citizenship behaviour and intention to stay with or leave organisations (Podsakoff et al. 2000).

As the business environment becomes more turbulent, "it becomes more pertinent to deliberately, consistently, strategically and innovatively develop, optimize and utilize their major value adding resource, i.e. human resource" (Akinyemi, 2011). This paper, therefore, examines the role of a positive HRDC in engaging and retaining valuable human resource in Nigeria's banking sector. It is divided into five sections, viz: introduction; background; methodology; discussions, summary and conclusions and; study limitations and future research directions.

\section{Background}

\subsection{Human Resource Development}

Human Resource Development (HRD) is not just about employee training and development. It consists of all 
activities relating to training, career and organisation development. It is the conscious and deliberate organisational and/or individual undertakings aimed at enhancing the skills, knowledge, ability and other attributes of an employee for effectiveness in current job demands and anticipated future challenges. It is making a continuous, long-term investment in ensuring a high-quality workforce capable of accomplishing the organisation's mission now and in the future. Harrison and Kessels (2004, p.4) define HRD as an oganizational process comprising "the skillful planning and facilitation of a variety of formal and informal learning and knowledge processes and experiences, primarily but not exclusively in the workplace, in order that organisational progress and individual potential can be enhanced through the competence, adaptability, collaboration and knowledge-creating activity of all who work for the organisation." Swanson (1995) sees HRD as a process aimed at performance improvement by developing and unleashing human expertise through organisation development and personnel training and development. Rao (1985) elaborately define HRD as "a process by which the employees of an organisation are helped, in a continuous, planned way, to: acquire or sharpen capabilities required to perform various functions associated with their present or expected future roles; develop their general capabilities as individuals and discover and exploit their own inner potential for their own and/or organisational development purposes; develop an organisational culture in which the supervisor-subbordinate relationships, teamwork, and collaboration among sub-units are strong and contribute to the professional well being, motivation and pride of employees."

Human Resource Development (HRD) was also defined as "a set of systematic and planned activities designed by an organization to provide its members with the opportunities to learn necessary skills to meet current and future job demands" (Werner and DeSimone, 2006 p.5). Werner and DeSimone described HRD as a function of HRM. But Rao (1995) opined that the scope of HRD is extended, at one side, to developing competencies of human resource by enhancing knowledge, building skill, changing attitude and teaching values, and at other side, creation of conditions through public policy, programs and other interventions to help people to apply these competencies for their own and others' benefits and making things happen. Stressing the ultimate goal of HRD in any country Bacchus (1992) posits that it is 'to improve the quality of life of all it's people and not merely concerned with providing necessary skills to individuals. The concept of HRD deals with many facets of development of individuals including their physical, intellectual, emotional, political, and spiritual aspects. In essence, HRD is tantamount to building competence, commitment and culture (Rao, 1990).

In the era of intense competition, rapidly changing technology, uncertainty, high customer expectations and demand, organisations cannot affort to trivialise the capability development of their employees. As stated by Dag Hammarskjöld, "fundamentally man is the key to all problems, not money. Funds are valuable only when used by trained, experienced, and devoted men and women. Such people, on the other hand, can work miracles even with small resources and draw wealth out of a barren land (UN 1995, p.3). Since HR is the major source of sustainable competitive advantage it should be strategically developed to meet current and future challenges. The effectiveness of organisations in developing their workforce largely depends on the prevailing developmental climate within the organisations.

\subsection{Organisational Developmental Climate}

Human resource development climate (HRDC) is a component of organisational climate. Organisational climate has been defined in various ways. According to Schneider (1990) it is individual perceptions about salient characteristics of the organisational context. Tagiuri and Litwin $(1968$, p. 25) define it as "the relatively enduring quality of the total environment that (a) is experienced by the occupants, (b) influences their behavior, and (c) can be described in terms of the values of a particular set of characteristics (or attributes) of the environment." Attributes of organisational climate are said to include: (1) a supportive climate, (2) a climate of risk taking, (3) a climate of cohesiveness, and (4) a climate with the motivation to achieve (Denison, 1996). Organisational climate is the set of characteristics that describe an organisation and that (a) distinguishes one organisation from other organisations; (b) are relatively enduring over time and (c) influence the behavior of the people in the organisation (Forehand and Gilmer, 1964). It includes the attention members pay to characteristics in the organisation such as policy, rewards, and management behaviors as well as meaning attached to these characteristics based on individual characteristics including value systems and needs.

Wexley and Latham (1991) noted that components of organsational climate such as compensation, opportunity for advancement, supervisory style, organisational goals, and concern for employees are related to transfer of training. Assessing the link between eight climate dimensions and post-training behaviors in over 100 units of a fast-food chain, Rouillier and Goldstein (1993) found that workers earned higher performance ratings in setting offering a more positive transfer climate. Using the Roeuiller and Goldstein climate questionnaire, Tracey et al. (1995) showed a direct relationship between climate and transfer of learning. Bennett et al. (1999) also found a link between various climate factors and the transfer of service quality training. Other researchers have also found that "organisational 
climate predicts positive work attitudes and behaviours. Employees are more satisfied working in a positive work environment and therefore less likely to leave their organisations (Pace, 2002; Aarons and Sawitzky, 2006).

\subsection{Organisational Citizenship Behaviour}

The notion of (OCB) was introduced by Bateman and Organ (1983, p.4) and defined as "individual behaviour that is discretionary, not directly or explicitly recognized by the formal reward system, and that in the aggregate promotes the effective functioning of the organisation" (Organ, 1988, p.4).

Although there is an increasing research interest in OCB, a consensus is yet to be reached regarding what the different types of behaviors constitute OCB. However, OCB is reported to have seven common themes. These are: helping behavior, sportsmanship, organisational loyalty, organisational compliance, individual initiative, civic virtue and self-development. OCB, therefore, may contribute to organisational success for the following reasons: enhanced co-worker and managerial productivity, freeing up resources that can be used for more productive purposes, helping to coordinate activities within and across groups, strengthening the organisation's ability to attract and retain the best employees, increasing the stability of the organisations performance and allowing the organisation to adapt more effectively to organisational changes (Podsadoff et al., 2000).

The impact of OCB on organisational output at both group and individual levels have been empirically established. It is positively related to both the quantity and quality of product output (Podsakoff et al., 1997), contributes to team effectiveness (MacKenzie, Podsakoff, and Ahearne, 1996, as cited in Podsakoff and MacKenzie, 1997). OCB has also been found to contribute to overall performance (Podsakoff and MacKenzie, 1994) as well as overall operating efficiency and customer satisfaction (Walz and Niehoff, 1996 as cited in Podsakoff and MacKenzie, 1997).

In a literature review of OCB, Podsakoff et al. (2000) identified 30 different forms of citizenship behaviour. These were classified into seven common themes to take care of conceptual overlaps between dimensions. The seven dimensions of citizenship behaviour as categorised by Podsakoff et al. (2000, pp. 516 - 526) are:

Helping behaviour involves voluntarily helping others with, or preventing the occurrence of, work-related problems (p.156).

Sportmanship defined as "a willingness to tolerate the inevitable inconveniences and impositions of work without complaining” (Organ 1990, p.96).

Organisational loyalty involves promoting the organisation to outsiders, protecting and defending it against external threats, and remaining committed to it even under adverse conditions (p.517).

Organisational compliance internalisation and acceptance of the rules, regulations and procedures which results in a scrupulous adherence to them, even when no one observes or monitors compliance (p.517).

Individual initiative is voluntary acts of creativity and innovation designed to improve one's task or the organization's performance persisting with extra enthusiasm and effort to accomplish one's job (p.524).

Civic virtue is willingness to participate actively in governance of organization (p.525).

Self development includes voluntary behaviours employees engage in to improve their knowledge, skills and abilities (p. 525).

This shows the multi-dimensional nature of OCB. It is, however, necessary to note that for this study OCB is defined as a collection of volunteer and non-obligatory behavior that is not defined in the official employee job descriptions but contribute to effective improvement of duties and roles in an organization (Cohen, et al, 2004).

A longitudinal study of a restaurant chain shows that OCB expressed in the first year is related to profitability in the second year (Koys, 2001). Another study of restaurants produced similar findings, showing that OCB was related to operating efficiency, revenue, fewer customer complaints, and quality of performance (Walz and Niehoff, 1996). Podsakoff, Ahearne, and MacKenzie (1997) found a connection to success outcomes at a paper mill where the quality of the paper accepted and the quantity produced was associated with expression of OCB. Actually, some dimensions of OCB may vary but overall OCB demonstrates a strong relationship to organisational effectiveness as earlier mentioned.

The views of Bergeron (2007) is quite relevant as far as the current situation in Nigerian banks is concerned. According to him, organisations need to recognize the non-availability of enough time for employees to devote to both task performance and OCB. Organisations are increasingly requiring their employees to work longer and longer hours (Bond, Galinsky, \& Swanberg, 1997; Reich, 2001). In the service industry, such as banks, where customer loyalty is of utmost importance OCB is highly required for service quality delivery.

\subsection{Voluntary Turnover Intention}

Most researches are concerned with VTI in organisations and it is commonly held that VTI is dysfunctional, 
adversely influencing organisational effectiveness, i.e. the degree to which organisations achieve their goals (Hom and Griffeth, 1995). VTI is "a conscious and deliberate wilfulness to leave the organisation" (Tett and Meyer 1993, p. 262). It is thinking about quitting one's current organisation and it is the best and most immediate predictor of turnover. Various reasons have been advanced in respect of employees' VTI. For instance, Lee and Bruvold (2003) concluded that investment in employee development correlated with employee intention to leave the organisation. However, intention to leave was fully mediated by job satisfaction and affective commitment. The lack of opportunities for career development has also been identified as the most important factor affecting employee retention. It is the view of some researchers that any company that would strengthen its bond with its employees has to invest in their development (Hall and Moss, 1998; Hsu, et al., 2000; Steel, et al., 2002). While creation of opportunities for promotion from within the company is essential, there must be opportunities for training and skill development that enable employees to enhance their employability on the internal and/or external labor market (Butler and Waldrop, 2001). Other factors such as the provision of mentoring or coaching to employees, organizing career management workshops and setting up of competency management programs all relate to career development (Roehling, et al., 2000).

In a study by Allen, Shore and Griffeth (2003) it was found that the lack of training and promotional opportunities resulted in high performers' turnover. Also, Steel et al (2002) reported empirical data showing that lack of training and promotional opportunities were the most frequently cited reason for high-performers to leave the company. Benson et al., (2004) studied the voluntary turnover of a large sample of manufacturing employees who were participating in tuition reimbursement programs. It appeared that while employees were still in school the voluntary turnover decreased. After graduation the turnover increased. If the degree was earned and the employee was subsequently promoted the turnover was significantly reduced. The researchers concluded that enhancing employees' general skills increased their marketability and therefore the perceived alternatives, which in turn, increases turnover. If promotion followed graduation, then the turnover decreased, and the negative impact on retention was stronger than when employees were promoted without attaining a degree. This would lead to satisfaction and commitment to the organisation (in line with social exchange theory).

Lto and Brotherridge (2005) examined the impact of supervisor support for development, career adaptability, affective commitment and turnover intentions and found the conflicting relations between enhancing employees' employability and attitudes with regards to turnover. Supervisor support for development was negatively related to intention to leave. From the above, it is clear that a positive HRD climate in organisations is a prerequisite for employee retention especially when development is followed by recognition and reward.

\subsection{The Nigeria Banking Sector}

The role of the banking sector in enhancing economic growth through financial intermediation is significant (Sanusi, 2011). Prior to 2004, the Nigerian banking sector was laced with so many anomalies induced largely by weak capital base. Continued reforms were, therefore, implemented to strengthen the sector by making it the main driver of growth (Ademosu, 2008). In 2005, bank recapitalisation exercise trimmed the number of from 89 to 25 through merger and acquisition to meet up with the 25 billion Naira capital requirement. In response to fresh challenges resulting from the recapitalised exercise, further comprehensive banking sector reforms were introduced in order to address poor corporate governance, and unethical practices in the industry. The reforms led to a further reduction in the number of banks as Central Bank of Nigeria (CBN) raised the Monetary Policy Rate (MPR) to 8.75 per cent to further tighten money supply in anticipation of future rise in inflation in the economy. These series of reforms have repositioned the banks such that some banks now compete effectively regionally and globally. For instance, nine banks have now made the list of top 1,000 World Banks ranking and top 25 banks in Africa (Udeme, 2011).

The implication of these reforms is that the right human capital - knowledgeable, exposed and cosmopolitan - is now critical" (Soludo, 2010). This has led to intense competition for the already stretched talent pool. So also is the dire need for and retention of highly skilled and knowledgeable workers through the implementation of effective HR strategies. These make the need for the study which examines HRDC's role in fostering employees' citizenship behaviour and their intention to stay with their organisations very significant. The study also provides empirical evidence in an area where empirical research is lacking especially relating to the Nigerian banking sector.

\section{Methodology}

An increasingly volatile business environment and growing expectations and aspirations of both internal and external customers require that organisations intensify their efforts to enhance employee performance through conscious, deliberate and strategic capability development. The primary purpose of the present field study was to explore the impact of organisational developmental climate on OCB and VTI. The study focussed on the perception of employees along three dimensions: 
- Extent of relationship between HRDC and OCB as perceived by employees;

- Level of relationship between HRDC and VTI according to employees' perception;

- The influence of OCB on employees' VTI.

The study was carried out within the commercial banks in South Western Nigeria. The questionnnaires were self administered to the executive and non-executive members of staff in the selected banks. The collected data was analysed using the Statistical Package for Social Sciences (SPSS) to calculate the means, standard deviations, t-tests, $r$ square and critical $t$ at 0.5 level of significance. Respondents rated their level of agreement with each item on a five-point Likert scale ranging from (1) strongly disagree to (5) strongly agree.

\subsection{Instruments}

The items within the scale originates from existing research scales on HRDC (Rao and Abraham, 1990), OCB (Podsakoff et al., 1990 and Williams and Anderson, 1991) and VTI (Camman, Fichman, Jenkins and Klesh 1979; Seashore, Lawler, Mirvis and Camman 1982) and the Lyons' Propensity to Leave scale (Cook, Hepworth, Wall and Warr 1981).

\subsection{Conceptual Model}

Based on the study dimensions (in 3 above), a conceptual model was developed as shown in Figure1. Insert Figure 1 Here

\subsection{Research Hypotheses}

Based on the above conceptual model the following hypotheses were formulated to be subjected to statistical test.

H1: There is no statistically significant relationship between HRDC and OCB.

H2: There is no statistically significant relationship between HRDC and VTI.

H3: There is no statistically significant relationship between VTI and OCB.

\subsection{Hypotheses Testing}

To test the hypotheses, the mean score, standard deviation and $\mathrm{r}$ squares as well as critical $\mathrm{t}$ were calculated. The results of these analyses are presented below.

Hypothesis 1: There is no statistically significant relationship between HRDC and OCB.

(Insert Table 1 here)

From the above table, a significant relationship exists between HRDC and OCB. The $r$ square of 0.36 shows about $36 \%$ relationship between OCB and HRDC. Similarly, the calculated t of 49.55 is higher than critical $t$ of 1.98 at $95 \%$ confidence internal. This implies that OCB is a function HRDC. The null hypothesis is, therefore, rejected.

Hypothesis 2: There is no statistically significant relationship between HRDC and VTI.

(Insert Table 2 here)

Statistical results from the above table indicate a significant relationship between HRDC and VTI, the $r$ square of 0.31 indicates about $31 \%$ relationship between HRDC and VTI. Also, the calculated t of 48.82 is higher than the critical $t$ of 1.98. This shows a significant difference between VTI and HRDC. Thus, voluntary turnover is influenced by HRDC. The null hypothesis is rejected.

Hypothesis 3: There is no statistically significant relationship between OCB and VTI.

(Insert Table 3 here)

The mean score of OCB (10.85) is slightly lower than of VTI (11.19). The r square of 0.14 shows about $14 \%$ relationship between OCB and VTI, and significant $(p<0.05)$. The calculated $t$ of 1.45 is less than critical t of 1.96 . As a result, there is no significant relationship between OCB and VTI. This implies that OCB does not influence VTI. The null hypothesis is, therefore, accepted.

\section{Discussion, Summary and Conclusions}

The Nigerian banking sector is one of the most vibrant sectors and a major contributor to national economic growth. Reforms opened the banking sector to intense competition and continued search for talented and highly skilled professionals. For any bank to gain the competitive edge in the current unpredictable business environment, it must focus on "building a more responsive, flexible and resilient workforce" (Akinyemi, 2009). The strategic role of HRDC in fostering extra-role behaviour and retention is the major thrust of this study. The study also examined the relationship between OCB and VTI. Results of data analysis show a relationship between HRDC and OCB (Table 1). 
A significant relationship also exists between HRDC and VTI (Table 2). However, no relationship exists between OCB and VTI (Table 3). Research evidence shows HR practices are strongly associated with OCB (Moorman, 1993; Deckop and Cirka, 1999; O’Bannon and Pearce, 1999). Results from another study (Biswas, 2010) show that psychological climate is the antecedent of organizational citizenship behaviour. Also found to be significantly related to citizenship behaviours is organisational characteristics such as group cohesiveness and organisational support (Podsakoff et al. 2000:526-533). These are significant parts of a congenial developmental climate. The findings of this study corroborate earlier research findings that significant relationship exists between organizational climate and positive work attitude and behaviours ((Pace, 2002; Aarons and Sawitzky, 2006). For service-oriented industries, such as banks, to enhance employees' citizenship behaviour a congenial developmental climate must exist.

HRDC is also seen to have significant relationship with VTI. This agrees with the results of other studies linking climate with turnover intention (Gormley, 2007; Hong and Kaur, 2008; Ribeiro-Tupinamba and Castro, 2011). Retention of talent is critical to the suvival of organisations especially during intense competition. This study is a contribution to previous studies that found significant relationship between climate and turnover intention. In order to retain highly skilled professionals each bank need to foster a conducive developmental climate that enhances innovation, team spirit, top management support, openness and cordiality.

Contrary to some research findings, this study finds no relationship between OCB and VTI. Khalid, et al. (2009) argued that "although other factors should also influence turnover, it is likely that employees with higher levels of OCB would report lower levels of turnover intention so as to preserve linkages to the organization." Based on some other research findings, Chen et al. (1998) concluded that "OCB might have an influence on employees' turnover intention." Ribeiro-Tupinamba and Castro (2011) identify variables that are significantly responsible for the employees' intention of moving to a company of another segment. These include "identification with the position", "technical orientation offered by supervisors", "socio-affective support" and "satisfaction with the organization". Investigating the effects of OCB on turnover intention and absenteeism among star-rated hotel employees in Malaysian, Ali, (2006) found a negative relationship with turnover intention. In a meta-analytic investigation of individual and organisational-level consequences of OCB, Podsakaff et al. (2009) found that OCBs are related to a number of individual-level outcomes, including managerial ratings of employee performance, reward allocation decisions, and a variety of withdrawal-related criteria (e.g., employee turnover intentions, actual turnover, and absenteeism).

\subsection{Practical and Managerial Implications of Findings}

This study shows that the VTI and OCB of Nigerian bank employees are related to their HRDC. Nigerian banks' management can reduce turnover and foster citizenship behaviour by ensuring that a favourable developmental climate exists within their organisations.

The results of this research have implications for practising managers since they are involved with managing human resources within the organisations. Managers should endeavour to provide a daily favourable working environment where employees are comfortable to develop and utilise their potentials without any form of inhibition. Managers should also regularly measure the prevailing climate within their units/organisations to understand the current nature of organisational developmental climate. This would provide managers with useful information that they could use to initiate series of action to mitigate any problem associated with negative workplace climate.

\section{Study Limitations and Future Research Directions}

This study examined HRDC's influence on OCB and VTI within Nigeria's banking sector. It also investigated the relationship between OCB and VTI within the Nigerian banking sector in the context of reform. The current study did not focus on some major challenges which confront bank employees during the reconsolidation exercise, such as, job losses and employment instability. Downsizing of employees and employment instability leading to organised unions opposition were not addressed in this study. This situation could, probably, have had serious implications for the results of this study. Further research on these emerging critical issues in the banking sector is therefore suggested as future research focus. This study found no significant relationship between OCB and VTI, contrary to earlier research findings. In fact, empirical research investigating the effects of the various dimensions of OCB on VTI and actual turnover in Nigeria are rarely given attention. It is, therefore, recommended that future research should focus more on this area.

\section{References}

Aarons, G. A., \& Sawitzky, A. C. (2006). Organizational Climate Partially Mediates the Effect of Culture on Work Attitudes and Staff Turnover in Mental Health Services. Adm Policy Ment Health, 33, 289-301. http://dx.doi.org/10.1007/s10488-006-0039-1 
Ademosu, E. A. (2008). Corporate Social Responsibility: The Experience of the Nigerian Banking System. Paper Delivered at the 2008 of the Federation of African Public Relations Associations (FAPRA) held on April 28 to May 2, 2008 at the Golden Tulip Hotel, Kumasi, Ghana.

Akinyemi, B. O. (2009). Human Capital Management for Sustainable Competitive Advantage in the New Economy. In Teresa Torres-Coronas \& Mario Arias-Olivia (Eds). Encyclopedia of Human Resources Information Systems: Challenges in e-HRM (441-450).

Akinyemi, B. O. (2011). Human Resource Development Climate in Rwanda Private Sector Organisations. International Bulletin of Business Administration, 12, 66-78.

Ali, K. H. (2006). Organisational Citizenship Behviour, Turnover Intention and Absenteeism among hotel employees. Malaysian Management Review, 41, 1.

Allen, D. G., Shore, L. M., \& Griffeth, R. W. (2003). The role of perceived organizational support and supportive human resource practices in the turnover process. Journal of Management, 29, 99-118. http://dx.doi.org/10.1177/014920630302900107

Bacchus, M. K. (1992). Human Resource Development: Definition, Importance and Strategies. London: Commonwealth Secretariat.

Bateman, T. S., \& Organ D. W. (1983). Job satisfaction and the good soldier: The relationship between affect and employee "citizenship". Academy of Management Journal, 26, 587-595. http://dx.doi.org/10.2307/255908

Bennett, J. B., Lehman, W. E. K., \& Forst, J. K. (1999). Change, transfer climate, and customer orientation: A contextual model and analysis of change-driven training. Group and Organisation Management, 24, 188-216. http://dx.doi.org/10.1177/1059601199242004

Benson, G. S., Finegold, D., \& Mohrman, S. A. (2004). You paid for the skills, now keep them: tuition reimbursement and voluntary turnover. Academic of Management Journal 47, 315-331. http://dx.doi.org/10.2307/20159584

Bergeron, D. M. (2007). The potential paradox of organizational citizenship behavior: Good citizens at what cost? Academy of Management Review, 32, 1078-1095. http://dx.doi.org/10.5465/AMR.2007.26585791

Biswas, S. (2010). Commitment as a Mediator between Psychological Climate and Citizenship Behaviour. Indian Journal of Industrial Relations, 45, 411-423.

Bond, J. T., Galinsky, E. \& Swanberg, J. E. (1997). The 1997 National Study of the Changing Workforce. New York: Families and Work Institute.

Butler, T., \&. Waldroop, J. (2001). Harvard Business Review on finding and keeping the best people. Boston: Harvard Business School Press.

Cammann, C., Fichman M., Jenkins, D., \& Klesh, J. (1979). The Michigan Organisational Assessment Questionnaire. Unpublished manuscript, University of Michigan, Ann Arbor, Michigan.

Chen, X. P., Hui, C., \& Sego, D. J. (1998). The role of organizational citizenship behavior in turnover: conceptualization and preliminary tests of key hypothesis. Journal of Applied Psychology, 83, 922-931. http://dx.doi.org/10.1037/0021-9010.83.6.922

Cohen, A., \& Kol, Y. (2004). Professionalism and organizational citizenship behavior an empirical examination among Israeli nurses. Journal of managerial psychology, 19, 386-405. http://dx.doi.org/10.1108/02683940410537945

Cook, J. D., Hepworth, S. J., Wall, T. D., \& Warr, P. B. (1981). The experience of work: A Compendium and Review of 249 measures and their Use. London: Harcourt Brace Jovanovich Publisher.

Deckop, J. R., Mangel, R. \& Circa, C. (1999). Getting More Than You Pay For: Organizational Citizenship and Pay-Performance Plans. Academy of Management Journal, 42, 420-428. http://dx.doi.org/10.2307/257012

Denison, D. R. (1996). What is the difference between organizational culture and organizational climate A native's point of view on a decade of paradigm wars? Academy of Management Review, 21, 619-654. http://dx.doi.org/10.5465/AMR.1996.9702100310

Forehand, G., \& Von Gilmer, B. (1964). Environmental variations in studies of organisational behaviour. Psychological Bulletin, 62, 362-381. http://dx.doi.org/10.1037/h0045960 
Gormley, D. K. (2007). Climate, Role and Commitment: Factors Influencing Turnover Intention in Nurse Faculty. [Online] Available: http://stti.confex.com/stti/bc39/techprogram/paper_35298.htm.

Hall, D, T., \& Moss, J. E. (1998). The new protean career contract: Helping organizations and employees adapt. Organizational Dynamics, 26, 22-37. http://dx.doi.org/10.1016/S0090-2616(98)90012-2

Hammonds, K. H. (2005). Why we hate HR. Fast Company, 97, 40-47.

Harrison, R., \& Kessels, J. W. M. (2004). Human Resource Development in a knowledge economy. An organisational view. Hampshire - New York: Palgrave Macmillan.

Hom, P. W., \& Griffeth, R. W. (1995). Employee turnover. Cincinnati, OH: Southwestern.

Hsu, M. K., Jiang, J. J., Klein, G., \& Tang, Z. (2003). Perceived career incentives and intent to leave. Information \& Management, 40, 361-369. http://dx.doi.org/10.1016/S0378-7206(02)00018-6

Jones, A. P., \& James, L. R. (1979). Psychological climate: Dimensions and relationships of individuals and aggregated work environments perceptions. Organisational Behaviour and Human Performance, 23, 201-250. http://dx.doi.org/10.1016/0030-5073(79)90056-4

Khalid, S. A., Ali, H., Ismail, M., Kassim, K. M., \& Rahman, N. A. (2009). Gender as a moderator of the relationship between OCB and turnover intention. Asian Social Science. 5, 6.

Koys, D. J. (2001). The effects of employee satisfaction, organizational citizenship behavior, and turnover on organizational effectiveness; A unit 0 level, longitudinal study. Personnel Psychology, 54, 101-104. http://dx.doi.org/10.1111/j.1744-6570.2001.tb00087.x.

Lee, C. H., \& Bruvold, N. T. (2003). Creating value for employees: Investment in employee development. International Journal of Human Resource Management, 14, 981-1000. http://dx.doi.org/10.1080/0958519032000106173

Lto, J. K., \& Brotherridge, C. M. (2005). Does supporting employees' career adaptability lead to commitment, turnover, or both? Human Resource Management, 44, 5-19. http://dx.doi.org/10.1002/hrm.20037

Moorman, R. H. (1993). The influence of cognitive and affective based job satisfaction measures on the relationship between satisfaction and organizational citizenship behavior. Human Relations, 46, 756-776.

Mullins, L. J. (2005). Management and organisational behavior. (7th ed.) Harlow: Prentice Hall.

O’Bannon, D. P., \&. Pearce, C. L. (1999). A quasi-experiment of gainsharing in service organization: Implications of organizational citizenship behavior and pay satisfaction. Journal of Management Issues, 11, 363 - 378.

Organ, D. W. (1988). Organisational Citizenship behavior: The good soldier syndrome. Lexington, MA: Lexington Books.

Organ, D. W. (1990). The subtle significance of job satisfaction. Clinical Laboratory Management Review, 4, 94-98.

Pace, R. W. (2002). Organisation Dynamism. West Port, CT: Quorum.

Podsakoff, N. P., Whiting, S. W., Podsakoff, P. M., \& Blume, B. D. (2009). Individual-and organizational-level consequences of organizational citizenship behaviors: A meta-analysis. Journal of Applied Psychology, 94, 122-141. http://dx.doi.org/10.1037/a0013079

Podsakoff, P. M., \& MacKenzie, S. B. (1994). Organisational citizenship behaviours and sales unit effectiveness. Journal of Marketing Research, 31, 351-363. http://dx.doi.org/10.2307/3152222

Podsakoff, P. M., MacKenzie, S. B., Moorman, R. H., \& Fetter, R. (1990). Transformational leader behaviors and their effects on followers' trust in leader, satisfaction, and organizational citizenship behaviors. Leadership Quarterly, 1, 107-142. http://dx.doi.org/10.1016/1048-9843(90)90009-7

Podsakoff, P. M., Ahearne, M., \& MacKenzie, S. B. (1997). Organisational citizenship behavior and the quantity and quality of work group performance. Journal of Applied Psychology, 82, 262-270. http://dx.doi.org/10.1037/0021-9010.82.2.262

Podsakoff, P. M., MacKenzie, S. B., Paine, J. B., \& Bachrach, D. G. (2000). Organisational citizenship behaviour: A critical review of the theoretical and empirical literature and suggestions for future research. Journal of Management, 26, 513-563. http://dx.doi.org/10.1177/014920630002600307

Rao, T. V., \& Abraham. E. (1990). HRD Climate Questionnaire (in Developing Human Resources: Annual), University Associates, USA.

Rao, T. V. (1990). The HRD Missionary. New Delhi: Oxford and IBH. 
Rao, T. V. (1995). HRD philosophies and Concepts the India perpective. National HRD network.

Rao, T. V. (1985). Integrated Human Resource Development Systems. In L.D Goodstein and J. W Pfeiffer The 1985 Annual Developing Human Resources Sandeigo C A: University Associates.

Reich, R. B. (2001). The Future of Success. Knopf.

Ribeiro-Tupinamba A. C., \& Castro, P. M. (2011). The Impact of Organizational Climate on the Turnover Intention of Call-center Employees. [Online] Available: http://ijm.cgpublisher.com/product/pub.28/prod.1287.

Roehling, M. V., Cavanaugh, M. A., Moynihan, L. M., \& Boswell, W. (2000). The nature of employment relationship: A content analysis of the practitioner and academic literatures. Human Resource Management. 39, 305-320. http://dx.doi.org/10.1002/1099-050X(200024)39:4<305::AID-HRM3>3.0.CO;2-V

Rouiller, J. Z., \& Goldstein, I. L. (1993). The relationship between organisational transfer climate and positive transfer of training. Human Resource Development Quarterly, 4, 377-390. http://dx.doi.org/10.1002/hrdq.3920040408

Sanusi L. S. (2011). Banks in Nigeria and National Economic Development: A Critical Review. Keynote Address at the Seminar on "Becoming An Economic Driver While Applying Banking Regulations", organized by the Canadian High Commission in Joint Collaboration with the Chartered Institute of Bankers of Nigeria (CIBN) and the Royal Bank of Canada (RBC) on March 7, 2011.

Schneider, B. (1990). Organizational climate and culture. San Francisco. CA: Jossey-Bass.

Seashore, S. E., Lawler, E. E., Mirvis, P., \& Cammann, C. (1982). Observing and Measuring Organisational Change: A Guide to Field Practice. New York: Willey.

Swanson, R. A. (1995). Human resource development: performance is the key. Human Resource Development Quarterly, 6, 207-13. http://dx.doi.org/10.1002/hrdq.3920060208

Soludo C. (2010). Banking on Nigeria - Banking Reforms Highlight Need for Skills. [Online] Available: http://www.reconnectafrica.com/careers-articles/sector-skills.html\#comp78. (August 15, 2011)

Steel, R. P., Griffeth, R. W., \& Hom, P. W. (2002). Practical retention policy for the practical manager. Academy of Management Executive, 16(2), 149-162. http://dx.doi.org/10.5465/AME.2002.7173588

Tagiuri, R., \& Litwin, G. (1968). Organizational culture: a key to financial performance. Organizational San Francisco: Jossey-Bass.

Tett, R., \& Meyer, J. (1993). Job Satisfaction, Organisational Commitment, Turnover Intendion, and Turnover: Path Analyses Based on Meta-Analytic Findings. Personnel Psychology, 46, 259-293. http://dx.doi.org/10.1111/j.1744-6570.1993.tb00874.x

Tracey, J. B., Tannenbaum, S. I., \& Kavanagh, M. J. (1995). Applying trained skills on the job: The importance of the work environment. Journal of Applied Psychology, 80, 239-252. http://dx.doi.org/10.1037/0021-9010.80.2.239

Ulrich, D. (1997). Human resource champions. Boston: Harvard Business School Press.

United Nations. (1995). Twelfth Meeting of Experts on the United Nations Programme in Public Administration and Finance. [Online] Available: http://unpan1.un.org/intradoc/groups/public/documents/un/unpan000780.pdf. (August 5, 2011).

Werner J. M., \& DeSimone, R. L. (2006). Human resource development. (4th ed. ) Mason, Ohio: Thomson-Southwestern.

Wexley, K. N., \& Latham, G. P. (1991). Developing and Training Human Resources in Organizations. (2nd ed. ) New York: Harper-Collins.

Williams, L. J., \& Anderson, S. E. (1991). Job satisfaction and organizational commitment as predictors of organizational citizenship and in-role behaviors. Journal of Management, 17, 601-617. http://dx.doi.org/10.1177/014920639101700305

Table 1. T-Test of HRDC on OCB

\begin{tabular}{|l|l|l|l|l|l|l|l|l|}
\hline & $\mathrm{X}$ & $\mathrm{SD}$ & Std error & $\mathrm{R}^{2}$ & Mean dff & $\mathrm{T}$ & Critical t & Sig p \\
\hline HRDC & 95.86 & 27.27 & 1.78 & & & & & \\
\hline OCB & 10.82 & 3.54 & 0.23 & 0.36 & 85.04 & 49.55 & 1.98 & 0.00 \\
\hline
\end{tabular}

Sig $\mathrm{p}<0.05, \mathrm{~N}=233$ 
Table 2. T-test of HRDC on VTI

\begin{tabular}{|l|l|l|l|l|l|l|l|l|}
\hline & $\mathrm{X}$ & SD & Std error & $\mathrm{R}^{2}$ & Mean dff & $\mathrm{T}$ & Critical t & Sig $\mathrm{p}$ \\
\hline HRDC & 95.61 & 27.20 & 1.77 & & & & & \\
\hline VTI & 11.33 & 2.58 & 0.17 & 0.31 & 84.52 & 48.82 & 1.98 & 0.00 \\
\hline
\end{tabular}

Sig $\mathrm{p}<0.05, \mathrm{~N}=233$

Table 3. T-test of OCB and VTI

\begin{tabular}{|l|l|l|l|l|l|l|l|c|}
\hline & \multicolumn{1}{|c|}{$\mathrm{X}$} & \multicolumn{1}{|c|}{ Std error } & \multicolumn{1}{|c|}{ Mean dff } & \multicolumn{1}{|c|}{$\mathrm{R}^{2}$} & \multicolumn{1}{c|}{ Critical t } & Df & Sig $\mathrm{p}$ \\
\hline OCB & 10.85 & 3.59 & & & & & & \\
\hline VTI & 11.19 & 2.62 & -0.35 & 0.14 & -1.45 & 1.96 & 300 & 0.15 \\
\hline
\end{tabular}

Sig $\mathrm{p}<0.05, \mathrm{~N}=233$

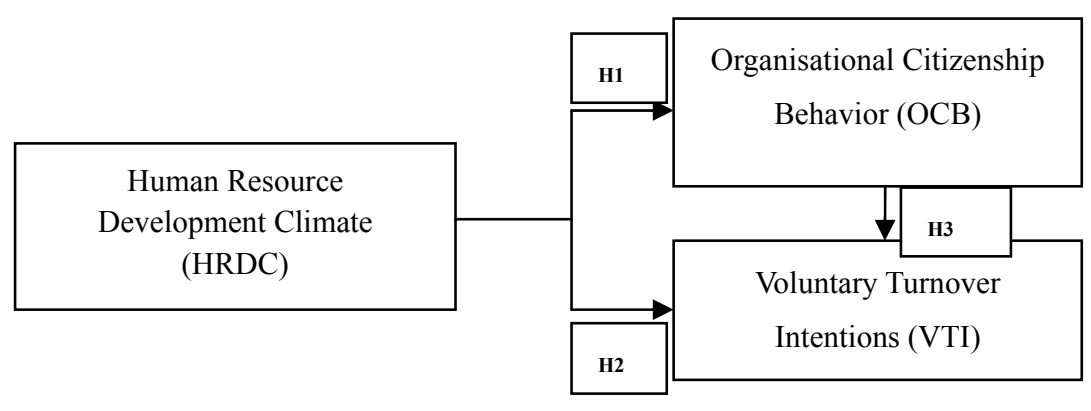

Figure 1. Conceptual Model 